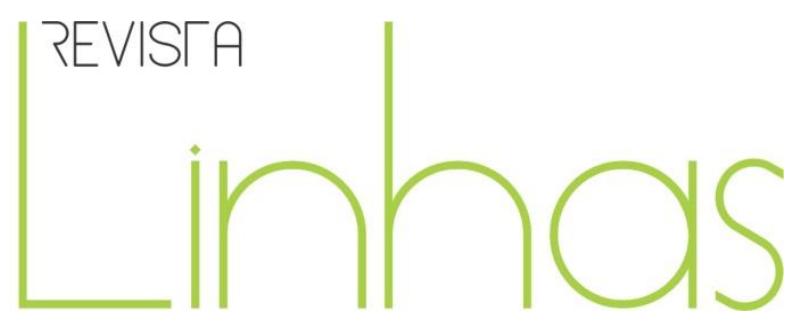

\title{
A experiência de Armanda Álvaro Alberto na Comissão de Censura Cinematográfica ${ }^{1}$
}

\begin{abstract}
Resumo
O presente artigo se propõe a trazer uma reflexão sobre a participação de Armanda Álvaro Alberto na Comissão de Censura Cinematográfica, enquanto intelectual da educação. Para isso desenvolve a ideia de intelectual e o seu papel social, o que era considerado como cinema educativo e o funcionamento da censura cinematográfica do período. Um trabalho desenvolvido durante o Governo Provisório, no contexto dos primeiros anos de Getúlio Vargas como presidente. Em abril de 1932 foi publicado o Decreto 21.240, que visava nacionalizar o serviço de censura de filmes cinematográficos e, para isso, previa a criação de uma Comissão. A metodologia utilizada tem apoio no conceito de intelectuais e de rede de sociabilidade usados por Jean-François Sirinelli. Como fontes, foram utilizados, principalmente, os documentos da Comissão de Censura Cinematográfica que pertenciam ao acervo do SEMEAR do Arquivo do Museu Nacional; a Revista Nacional de Educação e as referências bibliografias da intelectual analisada e do período histórico. Todo o acervo da Comissão de Censura Cinematográfica se perdeu no incêndio do Museu Nacional, que ocorreu em setembro de 2018.
\end{abstract}

Palavras-chave: cinema educativo; intelectual da educação; Armanda Álvaro Alberto; Comissão de Censura Cinematográfica.

\author{
Ana Gabriela Saba \\ Universidade Federal do Estado do \\ Rio de Janeiro - UNIRIO - Rio de \\ Janeiro/RJ - Brasil \\ anagabisa@gmail.com
}

\footnotetext{
Para citar este artigo:

SABA, Ana Gabriela. A experiência de Armanda Álvaro Alberto na Comissão de Censura Cinematográfica. Revista Linhas. Florianópolis, v. 22, n. 50, p. 88-110, set./dez. 2021.
}

DOI: $10.5965 / 1984723822502021088$

http://dx.doi.org/10.5965/1984723822502021088

\footnotetext{
${ }^{1}$ Pesquisa realizada com bolsa da Coordenação de Aperfeiçoamento de Pessoal de Nível Superior (CAPES).
} 


\title{
The experience of Armanda Álvaro Alberto at the Cinematographic Censorship Commission
}

\begin{abstract}
This article proposes to reflect on the participation of Armanda Álvaro Alberto in the Cinematographic Censorship Commission, as an educational intellectual. For this, he developed the idea of intellectuals and their social role, what was considered educational cinema and the functioning of film censorship in the period. A work developed during the Provisional Government, in the context of Getúlio Vargas' first years as president. In April 1932, Decree 21.240 was published, which aimed to nationalize the cinematographic film censorship service and for that purpose the creation of a Commission. The methodology used is supported by the concept of intellectuals and sociability network used by JeanFrançois Sirinelli. The sources used were mainly documents from the Cinematographic Censorship Commission that belonged to the SEMEAR collection of the National Museum Archives; the Revista Nacional de Educação and the bibliography references of the analyzed intellectual and historical period. The entire collection of the Cinematographic Censorship Commission was lost in the fire at the National Museum, which occurred in September 2018.
\end{abstract}

Keywords: educational cinema; intellectual of education; Armanda Álvaro Alberto; Cinematographic Censorship Commission. 


\section{Introdução}

Na virada do século XIX para o XX foi criado o recurso cinematográfico para comunicação e arte. Precursor na individualização das telas, o cinema era coletivo. Logo foi percebido e utilizado como instrumento educativo e, portanto, houve a necessidade de regras e arbítrios sociais para que sua exibição acontecesse. No Brasil, desde a década de 1910, havia leis em defesa dos menores, que se aplicavam ao cinema. Mas antes mesmo que se formasse um instituto específico para as normatizações sobre o cinema, foi criada no início do governo de Getúlio Vargas, em 1932, uma legislação que inaugurava uma organização de caráter nacional para o cinema, o Decreto 21.240. Esse decreto nacionalizou a censura cinematográfica e criou uma taxa para a censura, além de estabelecer a formação de uma comissão para avaliação dos filmes que seriam exibidos em território nacional.

A Comissão de Censura Cinematográfica teria validade de um ano e seria formada por cinco membros do Distrito Federal, podendo seus membros ser redirecionados ao cargo. A composição da Comissão seria constituída por um representante do Chefe de Polícia; um representante do Juízo de Menores; pelo diretor do Museu Nacional; por um professor designado pelo Ministério da Educação e Saúde Pública; e por uma educadora, indicada pela Associação Brasileira de Educação. Para ocupar o último cargo mencionado para a Comissão e único a ser representado por uma mulher, foi indicada Armanda Álvaro Alberto.

Na documentação pesquisada na Seção de Memória e Arquivo do Museu Nacional (SEMEAR/MN) foi possível perceber que o trabalho da Comissão ocorreu de 1932 a 1935, sendo que neste último ano foi sendo consideravelmente diluído. Não foi encontrada referência à finalização da Comissão, mas houve uma transição das tarefas executadas com a criação do Instituto Nacional do Cinema Educativo (INCE) em 1936. Com os recursos obtidos pela taxa de censura cinematográfica, o Decreto previa a criação de um instrumento que servisse para a educação popular, o que foi contemplado na Revista Nacional de Educação (1932-1934).

O presente artigo tem como objetivo trazer uma reflexão sobre a atuação de Armanda Álvaro Alberto na Comissão de Censura Cinematográfica. Um caso 
emblemático, a educadora trabalhou nas esferas públicas nos primeiros anos do Governo Provisório e após ter sido decretada a ditadura varguista em 1937, ela sofreu perseguição política e foi presa e libertada algumas vezes no período ditatorial do governo. Para isso, foram utilizados como fontes: dados bibliográficos da trajetória da educadora, histórico dos primeiros anos do governo de Getúlio Vargas e documentos do trabalho realizado pela Comissão de Censura Cinematográfica. O referencial teórico remete às reflexões de alguns autores como: a compreensão do papel do intelectual para Jean-François Sirinelli (2003); a abordagem da história intelectual de Carlos Eduardo Vieira (2008); a biografia de Armanda em Ana Chrystina Mignot (2010); as observações sobre o intelectual no governo Vargas nas autoras Ângela de Castro Gomes (1999, 2005), Silvana Goulart (1990) e Beatriz Kushnir (2004), sendo esta última importante no entendimento sobre a censura junto com Daniel Pécaut (1990).

Para lograr o objetivo analítico da reflexão a que o artigo se propõe, foram elaboradas as seguintes partes para estruturá-lo: Armanda, uma intelectual da educação; O Governo Provisório e a censura; O cinema educativo e a censura cinematográfica; $O$ trabalho da Comissão de Censura Cinematográfica; e Considerações.

\section{Armanda, uma intelectual da educação}

O aparecimento do termo intelectual é datado historicamente. Ao longo da história, o conhecimento de alguns poucos homens foi sendo valorizado em detrimento de outros. Esses conhecimentos estavam ligados a saberes que foram sendo considerados cultos e eruditos em relação aos demais da população, especialmente com o surgimento da escrita e seus detentores. Em determinado momento histórico, este homem culto passou a ser identificado como intelectual. O educador Carlos Eduardo Vieira (2008) elucidou o caminho percorrido no entendimento da formação do grupo, que atualmente é considerado e estudado como intelectual, desde a utilização do termo intelligentsia. O vocábulo começou a ser usado no fim do século XIX na Polônia e na Rússia, para designar os cultos da sociedade com sensibilidade e responsabilidade em relação à educação do povo e afirmação da nação. 
No cenário francês do fim do século XIX, grande parte do debate russo sobre as elites culturais fora apropriado, no termo "intelectual” que ganhou novas dimensões. Os intelectuais seriam o conjunto de homens cultos de determinada sociedade, protagonistas políticos com identidade definida e com possibilidade de transgressão, o que compreendia a grande novidade da prática intelectual em relação à prática da intelligentsia. Essa nova possibilidade de transgressão eclodiu a partir de um acontecimento que consolidou a ruptura com o sentido anterior: o caso Dreyfus, quando, em 1898, o intelectual Émile Zola tornou pública a sua oposição a uma atitude política do governo francês. Os intelectuais com seus saberes e representação na sociedade teriam um compromisso com a pátria e com seu governo. A atuação de Zola abriu precedente para que intelectuais de diversas áreas pudessem estar do lado oposto às proposições do governo da nação à qual pertenciam, entretanto, como traidores da pátria.

A palavra estava associada às elites e ao fato de considerarem que os intelectuais detinham a capacidade de analisar melhor as nuances sociais. O que se dava por uma produção cultural, em que os considerava com destacado papel político e detentores da verdade estabelecida e oficializada como comum ao povo da nação. O protagonismo político dos intelectuais foi possível em grande parte pela circulação de jornais e revistas. O historiador Peter Burke (2003, p.57) explicitou que os lugares comuns, como bibliotecas e outros espaços públicos facilitavam a interação dos homens de ação e dos homens de conhecimento, como nobres e artesãos; esta era a forma de sociabilidade que repercutia na produção e distribuição do conhecimento da época.

O historiador Jean-François Sirinelli analisou os intelectuais como um grupo social de contornos vagos, de limites imprecisos, sem um partido que os represente, portanto, “o estudo dos intelectuais como atores do político é complexo" (SIRINELLI, 2003, p. 244). Para o autor, a definição de intelectual possui uma geometria variável, desembocando em duas acepções do intelectual: uma ampla e sociocultural, englobando os criadores e os “mediadores” culturais; e outra mais estreita, baseada na noção de engajamento, sendo importante que o historiador considere ambas durante a pesquisa.

A partir da abordagem das acepções do intelectual, consideradas por Sirinelli (2003), propõe-se a observação para a intelectual da educação: Armanda Álvaro Alberto, que foi membro do Conselho Diretivo da Associação Brasileira de Educação (ABE) e, por 
isso, educadora indicada para compor a Comissão de Censura Cinematográfica. Suas práticas educativas, inspiradas no legado de Maria Montessori e inseridas nas propostas da Escola Nova, estavam voltadas para atender às crianças que sofriam com as desigualdades sociais e com dificuldades de ingressar nas escolas. No intuito de atender a demanda escolar dos filhos dos trabalhadores, Armanda fundou a Escola Regional de Meriti, em 1921. Uma escola que preconizava a igualdade de gênero e raça. Na sua criação, Armanda levou em consideração o ato de incorporar a população do interior à civilização através da educação, assumindo a educação como uma verdadeira missão (MIGNOT, 2010, p. 144).

A educadora possuía um grupo de amigos intelectuais, pertencentes à elite, com o qual dialogava sobre a educação e as questões relativas ao seu tempo. Pessoas que a apoiavam, incentivavam e ajudavam em seus projetos pessoais e coletivos. Entre os mais próximos estavam seu irmão Álvaro Alberto, Francisco Venâncio Filho e Edgar Sussekind de Mendonça que, em 1928, se tornou seu marido. Em 1920, Armanda colaborou na Associação Cristã Feminina (ACF), uma reunião de mulheres de todo o Brasil e estrangeiras de credos diferentes. Armanda atuou na Liga Brasileira contra o Analfabetismo, sendo vice-presidente em 1923. Em 1932, foi uma das três mulheres signatárias do Manifesto dos Pioneiros da Educação Nova. Uma educadora ativista em diversas frentes relevantes em seu tempo, mas menos conhecida do que muitos de seus contemporâneos. O que teria ocorrido, de acordo com a professora Ana Chrystina Mignot (2010), pelo fato de Armanda não estar inserida no ambiente teórico da escrita.

Na reflexão sobre os intelectuais, Sirinelli destaca a importância de se olhar para as redes de sociabilidade que estes frequentam. Elas variam de acordo com a época e o subgrupo de intelectuais estudados. As redes de sociabilidade no meio intelectual formam um "pequeno mundo estreito", no qual os laços se atam, por exemplo, em uma revista (SIRINELLI, 2003, p.248). As fontes documentais que formam essas redes são muito importantes para a compreensão dessas estruturas.

As redes definem as estruturas de sociabilidade; elas não são facilmente perceptíveis e possuem duas diferentes naturezas. A primeira delas são as revistas, que além de servirem de observatório para a sociabilidade dos intelectuais, também são utilizadas para análise do movimento das ideias. A segunda se refere aos manifestos e 
abaixo-assinados, quando o pesquisador se pergunta sobre a formação dos grupos de apoio e servem ainda para análise das correntes ideológicas clássicas. As redes guardam microclimas, nos quais a atividade e o comportamento dos intelectuais apresentam traços específicos.

Outro elemento importante sobre as redes de solidariedades, de um período específico, pode ser relacionado à noção de geração. Conforme destacou a historiadora Ângela de Castro Gomes (1999), a importância dos "lugares" de sociabilidade de uma geração, como as escolas, associações intelectuais, revistas, salões, podem ser componentes preciosos no entendimento da produção e circulação de ideias. Um espaço geográfico de sociabilidade é também afetivo, capaz de mostrar relações de proximidade e desentendimento, amizade e hostilidade desses intelectuais. Logo, as noções de geração e sociabilidade tornam-se importantes instrumentos analíticos operacionais para estudo.

\section{O Governo Provisório e a censura}

A jovem república brasileira teve de 1930 a 1945 Getúlio Vargas na presidência do país. Foram 15 anos marcados por transições políticas até a instauração da ditadura varguista iniciada em 1937. A primeira fase, conhecida como Governo Provisório, que foi até as eleições de 1934, ficou marcada por grandes mudanças, como a formação de ministérios, movimento constituinte, voto feminino. Modificações estas que acompanhavam um fluxo mundial de renovações, mas que foram apropriadas pelo governo em seu caráter populista. Houve um intenso trabalho de centralização do governo, em uma nacionalização do país. Com o estabelecimento do governo de Getúlio Vargas, os políticos e apoiadores se diziam renovadores da política brasileira, com o discurso de que fariam um país novo, onde o velho ficaria para trás e precisava ser apagado em favor de uma nova história, pelo novo governo. Esse era o discurso dos governantes no pós-1930 que invalidava o período anterior como “velho", uma República Velha fracassada, como sendo um equívoco (GOMES; ABREU, 2009, p.3).

A prática de desconsiderar o passado para legitimar o presente e suposto profícuo futuro, é recorrente na política brasileira e em muitas relações sociais. Na Proclamação da 
República no Brasil isso não foi diferente; a monarquia passou, já no final do século XIX, a ser vista pelos republicanos como um atraso, de privilégios para poucos, governo hereditário, ao contrário da república que representava a liberdade, a soberania popular, cidadania (MELLO, 2009, p.16).

Os meios para legitimação do governo e sua centralização eram muitos, sendo a educação e a cultura focos especiais para se lograr tais finalidades. É importante ressaltar que as políticas públicas nacionalizadas nesse governo não foram criações desse período, mas vinham de construções anteriores. Em relação ao campo da educação, na década de 1920 já havia efervescentes movimentos estaduais em prol da renovação educacional, influenciados pelo movimento da Escola Nova. Essas ideias e seus elaboradores incidiam em políticas públicas específicas nos estados. A partir de 1930, ocorreu uma centralização destas e muitos dos intelectuais da educação que as elaboraram passaram a participar ativamente do processo de nacionalização das políticas públicas.

No decorrer do governo Vargas, os intelectuais ocuparam lugares antagônicos da sociedade, e se apresentavam em dimensões heterogêneas. O Estado atribuía três papéis complementares aos intelectuais: o de concorrer para a definição das finalidades da ação política; o de expressar a presença da sociedade civil; e o de dar o exemplo de um ator social coletivo. Esses papéis foram interpretados como três atributos pelo discurso teórico: definir o que fundamenta a unidade social e o que se relaciona ao ato transformador; revelar a realidade; e formar corporação que assumisse interesse geral (PÉCAUT, 1990, p. 73). Portanto, aos intelectuais cabia um papel essencial do projeto de centralização nacional.

Nesse contexto foi estabelecido, por Francisco Campos, então Ministro da Educação e Saúde Pública, o Decreto 21.240, de 4/4/1932. O Decreto criou a Taxa de Censura Cinematográfica em prol da Educação Popular e outros fins. Esse decreto (BRASIL, 1932) propunha a criação de uma comissão de censura para a avaliação dos filmes educativos e, a partir da taxa arrecadada, previa a criação de veículo de circulação nacional para ampliar o acesso à educação. A Revista Nacional de Educação (RNE) foi esse veículo e circulou entre 1932 e 1934. A taxa ficou a cargo do Departamento de Ensino, vinculado ao Ministério da Educação e Saúde Pública, que repassaria a verba a seus devidos fins. 
O vocábulo censura causa incômodo, por remeter a algum tipo de coerção. Pensar em uma legislação, que previa que os recursos angariados pela censura cinematográfica serviriam à produção de material para a educação popular, é curioso, mais ainda quando educadores fazem parte do grupo dos censores. Mas que censura seria essa? Por que esses filmes deveriam ser censurados? Em que contextos se dava tal censura? Alguns historiadores elucidaram sobre a censura aplicada pelos governos e a importância dos intelectuais nesse exercício.

Para a historiadora Silvana Goulart (1990), a censura é parte do projeto da coerção do aparelho de Estado, que intimida, coíbe manifestações culturais diversas, reforça a autocensura e reduz a capacidade de contrainformação. Em sua análise sobre o primeiro governo de Vargas, a autora observou o lugar em que o Estado se colocava, de responsável pela suposta proteção do povo, isso aliado a uma necessidade de forjar uma consciência política nacional. Para a formação de uma consciência nacional, Silvana Goulart (1990, p.102) ressaltou a importância do trabalho do intelectual: "O intelectual era considerado ponto de união entre o governo e o povo, encarregado de perceber, no futuro próximo, as indicações dos rumos a seguir, traçados pela nova política do Brasil."

A observação da historiadora Beatriz Kushnir (2004) é fundamental para a compreensão da relevância do intelectual como elemento de ligação e censores na década de 1930. A autora aponta para o caráter intelectual que a censura ganhava, como um modo de "legitimação teórica" do próprio governo:

O estigma de um intelectual que colabora para um governo, sendo também um censor, é tão forte que, quando a Censura esteve vincula ao Ministério da Educação, foram estes que compuseram o conselho dos que aprovavam ou vetavam. Esse enlace, na ditadura varguista, apontou um caráter reflexivo que o ofício censório possuía. Tal imagem perdurou e muitos censores a tinham como um trabalho de cunho intelectual. (KUSHNIR, 2004, p. 172)

Outra contribuição para a reflexão da atuação dos intelectuais na censura, na década de 1930, veio do historiador Daniel Pécaut (1990): 
A censura existiu desde os primeiros anos, sendo exercida sem limites com a prorrogação do Estado Novo e a interdição dos partidos políticos. A repressão e a propaganda agiam duramente. O patriotismo era inculcado, seja nas escolas ou nas associações esportivas... As atividades culturais eram vigiadas. Esses fatos, entre muitos outros, não pareciam evoluir numa direção favorável àqueles intelectuais que não se sentiam atraídos pelas funções de propagandistas ou teóricos do autoritarismo. (PÉCAUT, 1990, p. 67)

\section{O cinema educativo e a censura cinematográfica}

O cinema educativo estava baseado nas propostas da Escola Nova em sua produção educativa e segundo Jorge Rangel (2010), constituiu um poderoso instrumento de cultura, de informação, de propaganda e de ensino. Mas o que era especificamente um filme educativo para os intelectuais que o produziam? Em um pronunciamento de Roquette Pinto, explicou tal questão, a partir da confusão gerada pela aproximação entre cinema educativo e cinema instrutivo. Nele apontou também a diferença entre educação e instrução e fez uma crítica à instrução sem a educação.

Não é raro encontrar, mesmo no conceito de pessoas esclarecidas, certa confusão entre o cinema educativo e o cinema instrutivo. É certo que os dois andam sempre juntos e muitas vezes é difícil ou impossível dizer onde acaba um e começa o outro, distinção que aliás não tem de fato grande importância na maioria das vezes. No entanto é curioso notar que o chamado cinema educativo, em geral não passa de simples cinema de instrução. Porque o verdadeiro educativo é outro, grande cinema de espetáculo, o cinema da vida integral. Educação é, principalmente ginástica do sentimento, aquisição de hábitos e costumes de moralidade, de higiene, de sociabilidade, de trabalho e até de vadiação... Tem que resultar do atrito diário da personalidade com a família e com o povo. A instrução dirige-se principalmente à inteligência. $O$ indivíduo pode instruir-se sozinho, mas não se pode educar senão em sociedade. O bom senso irônico do povo marcou espontaneamente a situação do instruído deseducado quando se riu do ferreiro que usa espeto de pau. São, pois muito grandes as responsabilidades do cinema de grande espetáculo. (RIBEIRO, 1944, p. 4)

Abaixo, o comentário de Jorge Rangel sobre obra do educador Fernando de Azevedo, em que este tratava da cultura brasileira. No trecho, há uma explicação sobre o potencial educativo associado ao cinema na época. 
No caso do cinema, seu poder educativo residiria na capacidade, por um lado, em fazer convergir para o mesmo centro, universalidade e identidade, no esforço de compreensão dos povos; por outro, na capacidade de transportar por toda parte a realidade presente, a sucessão de acontecimentos e a diversidade dos cenários com suas múltiplas paisagens sociais. (RANGEL, 2010, p. 45)

A censura aos filmes data de período anterior ao governo de Getúlio Vargas no Brasil. Havia, desde o início das exibições cinematográficas, uma preocupação com a força e o espaço que esse meio de comunicação ganhava entre a população, com a intensidade da produção de imagens e uma maior aproximação com o real. Acreditava-se que as produções poderiam ser fontes de contágio de maus hábitos. O cinema era encarado como uma diversão e isso chamou a atenção do Estado. Em meados da década de 1910, já apareciam as discussões a respeito da necessidade de uma legislação para a regulamentação da censura dos filmes cinematográficos. A inquietação em relação aos filmes tinha a intenção de defesa dos menores, das mentalidades que se formariam e logo precisariam ser defendidas daquilo que parecia uma ofensa aos valores a serem guardados e praticados pelos menores (SOUZA, 2003).

O Decreto $n^{\circ} 14.529$, de 9 de dezembro de 1920, foi a primeira iniciativa postulada em extensa legislação federal para a organização das diversões e espetáculos públicos. Há alguns relatos do período que mencionam ser tardia tal legislação, levando em consideração que na década de 1910 já havia salas de exibição de filmes pornográficos. Neste decreto (BRASIL, 1920) é interessante destacar a repercussão do artigo $n^{\circ}$ 59, que previa que os espetáculos impróprios à infância seriam vedados aos menores de 14 anos desacompanhados de seus pais ou responsáveis. A discussão se deu a respeito da incapacidade dos pais em definir, em alguns momentos, o que seria próprio à educação de seus filhos, por isso tal questão deveria estar a cargo do Estado (SOUZA, 2003, p. 31).

A historiadora da educação Sônia Câmara salienta que, na década de 1920, o uso do cinema na ação educativa constituiu-se como elemento sugestivo e útil na difusão da cultura brasileira e dos costumes nacionais, buscando por intermédio do "bom" cinema mostrar o "Brasil aos brasileiros" (CÂMARA, 2006 apud RANGEL, 2010, p. 55).

Uma das inovações da proposta de ensino era utilizar o cinema como recurso para a educação moderna. Recurso este utilizado por Armanda Álvaro Alberto na Escola 
Regional de Meriti. O cinema passou a ser visto como forma de ensino, uma verdadeira atividade pedagógica. A rádio e o cinema eram considerados meios propulsores no acesso à educação, por conseguirem alcançar, inclusive, aqueles que ainda eram analfabetos. Em um momento político em que a nacionalização era o alvo do governo, foi importante buscar acessar o Brasil em todas as suas partes. O Decreto 21.240 e o trabalho de censura da Comissão de Censura Cinematográfica estavam inseridos neste contexto histórico, realizado no Rio de Janeiro, então capital do país, e era levado ao Brasil.

Alguns meses após a tomada de poder por Getúlio Vargas, uma comissão da $A B E$ entregou uma representação ao chefe de polícia do Rio de Janeiro sobre a questão da censura dos filmes. Ela pedia um rigor maior na aplicação dos dispositivos regulamentares quanto ao decoro público, sugerindo que, para o futuro, houvesse a organização de um conselho destinado a lançar as bases de uma censura policial mais severa, sob todos os ângulos, abrangendo tanto os cinemas como os teatros e as publicações de qualquer espécie.

Vargas respondeu ao apelo da $\mathrm{ABE}$ e da Associação Cinematográfica dos Produtores Brasileiros e pediu que se organizasse uma comissão para o estudo da questão; esta seria presidida pelo Ministro Francisco Campos. Compunham o grupo: M. A. Teixeira de Freitas, Lourenço Filho, Jônatas Serrano, Francisco Venâncio Filho, Mario Behring, Ademar Gonzaga, Ademar Leite Ribeiro e outros, que elaboraram um anteprojeto que veio a se converter em lei. O "Projeto do Decreto que nacionaliza o serviço da Censura Cinematográfica", de 13 de janeiro de 1932, com dezenove páginas, pertencia aos arquivos da Comissão de Censura Cinematográfica. Deste projeto surgiu o Decreto 21.240 .

\section{O trabalho da Comissão de Censura Cinematográfica}

O acervo da Comissão de Censura Cinematográfica, que estava no Museu Nacional até o incêndio ocorrido no dia 2 de setembro de 2018, foi fundamental nesta pesquisa. $\mathrm{Na}$ documentação havia folhas de pagamento e gratificações dos membros da comissão e dos que colaboravam com a Revista Nacional de Educação; as listas mensais dos filmes que passavam pela censura da comissão; recortes de jornais com notícias sobre o Decreto 
21.240, o desempenho do trabalho da Comissão e da Revista; cartas de pessoas vindas de vários estados brasileiros em elogio à Revista; além das atas completas dos preparativos e realização do Convênio Educativo.

A censura dos filmes, realizada pela comissão com esta finalidade, era publicada mensalmente no Jornal do Brasil, Jornal do Comércio, Diário Carioca e O Globo, além da divulgação na Rádio Sociedade. Essa ação evidencia a relevância da impressa e da rádio como meios de comunicação na difusão de notícias no período. Proposição esta afirmada pelo historiador Nelson Werneck Sodré (1999), que destacou a terceira década do século $\mathrm{XX}$, como de grande desenvolvimento para a imprensa no Brasil.

No ano de 1932, logo após a nomeação dos membros da Comissão de Censura Cinematográfica, em 30 de abril, o trabalho de censura dos filmes começou a ser realizado. A maior parte dos filmes cinematográficos era aprovada nas seguintes categorias: filme educativo; impróprio para menores; ou aprovado mediante cortes ou correções. Os filmes proibidos para exibição eram pouquíssimos, nos anos de 1933 e 1934, não alcançando o percentual de $1 \%$ das películas cinematográficas avaliadas. De acordo com os relatórios dos filmes que passavam pela avaliação da comissão de censura, podese observar quantitativamente o trabalho desempenhado. O total de filmes classificados por ano foi de: 717, a contar de abril de 1932; 1.545 em 1933; e de 1.907 em 1934. Nesses três anos, 4.169 películas passaram pelo julgamento dos membros da Comissão de Censura Cinematográfica.

Observou-se que ocorreram mudanças nos parâmetros de avaliação das películas. No ano de 1932, na lista dos filmes aprovados e proibidos para exibição havia uma mesma categoria para justificar sua classificação: impróprio para crianças, impróprio para menores, crianças e senhoritas. Nos anos seguintes não foram mais divulgados os motivos para a proibição de exibição dos filmes, que assim foram qualificados. Ocorreu ainda, nos anos de 1933 e 1934, uma diminuição significativa em relação ao quantitativo de películas com exibição proibida. Os números referentes às proibições foram de 17, 3 e 5, respectivos aos três anos analisados de trabalho da Comissão.

O Decreto 21.240 (BRASIL, 1932) previa a realização de um Convênio Cinematográfico Educativo, a ser realizado cento e oitenta dias da publicação do Decreto, que aconteceu em janeiro de 1933. O evento, que ocorreu entre os dias três e cinco, foi 
um marco importante no trabalho da Comissão de Censura Cinematográfica e suas proposições apresentam o ensejo da necessidade de um órgão específico para tratar o tema do cinema educativo, como foi criado nos anos seguintes. Na documentação não há o nome de todos os que compareceram, mas há indicação de muitos deles e a quem era permitido estar no Convênio: representante do Governo Federal; os membros da Comissão de Censura Cinematográfica; os delegados dos Interventores; os industriais da cinematografia e os professores e educadores que se inscreverem. Como delegados dos Estados estiveram: Rodolfo Mota Lima de Alagoas, Anísio Spinola Teixeira, da Bahia; Benedito Silva, de Goiás; Generoso Ponce Filho, do Mato Grosso; Erasmo Pilloto, do Paraná; Silvio Rabelo, de Pernambuco; Deodato Maia, de Sergipe; Diniz Junior, de Santa Catarina; Fernando de Azevedo, de São Paulo; Francisco Venancio Filho, do Rio de Janeiro; e M.A. Teixeira de Freitas, do Piauí.

Em uma das caixas da documentação da Comissão de Censura Cinematográfica, que guardavam o acervo, havia muitos recortes de jornal referentes ao trabalho da Comissão pelo Decreto 21.240, da Revista Nacional de Educação e do Convênio. Uma das reportagens apresentava imagem do salão nobre do Museu Nacional, onde ocorreu o Convênio, repleto dos seus participantes. Vale destacar que além de Armanda Álvaro Alberto, membro da Comissão, só pode-se perceber a presença de outra mulher no evento porque esta fizera uma proposta. O evento possuía uma organização prévia, havendo um limite de três dias antes do seu início para as sugestões de propostas, para que houvesse tempo de serem reproduzidas aos participantes e estes tivessem parâmetros para o debate e votação. As atas dos três dias de reunião desse evento apresentavam caloroso debate em algumas questões e votação para quarenta e cinco propostas pelos participantes.

As considerações postuladas, pelos membros da Comissão de Censura Cinematográfica, estavam baseadas nas experiências das suas trajetórias pessoais e no trabalho desenvolvido pela Comissão. O Convênio Cinematográfico Educativo tinha suas finalidades, de acordo com o artigo 15, inciso $1^{\circ}$ do Decreto 21.240 (BRASIL, 1932), sendo: a instituição de cine-jornal, filmado no Brasil e com motivos brasileiros para inclusão quinzenal pelos exibidores; a instituição permanente de espetáculos infantis, de finalidade educativa, quinzenais para os cinemas públicos em horários populares; 
incentivo e facilidades econômicas para as produtoras de filmes nacionais; e apoio ao cinema escolar.

Para contemplar as finalidades do Convênio e a discussão das propostas, estas foram divididas em quatro grupos. Após o debate, algumas delas foram dispensadas para o momento, outras votadas e outras compreendidas como fora do intuito do evento. A documentação possuía a transcrição das manifestações dos participantes e resumo das mesmas. Um sucinto pronunciamento de Edgar Roquette Pinto, diretor do Museu Nacional, presidente da Comissão e do Convênio, deu início ao evento, ao qual pertence o seguinte trecho:

O Brasil não tem sabido tirar partido das possibilidades educativas do rádio, do cinema e do fonografo. No entanto, a 4 de abril de 1932, o presidente Getúlio Vargas deu um passo decisivo, quanto ao cinema, no decreto 21.240.

Por esse decreto, foram concedidos grandes favores fiscais a indústria e ao comercio cinematográfico, ao mesmo tempo que foi nacionalizado o serviço de censura dos filmes, que deixou de ser meramente "policial", para tornar-se francamente "cultural".

Ainda por força desse ato, criou o Governo Provisório a taxa cinematográfica para a educação popular, que é rigorosamente destinada a custear serviços de instrução popular, no sentido mais amplo da expressão. Desta arte, o cinema não só poderá educar, por si mesmo, como também concorrer para o desenvolvimento de outros meios educativos, com idêntico fim.

Tudo foi centralizado, naturalmente no Ministério da Educação. (ROQUETTE-PINTO, 1933)

Esse discurso inicial evidencia a principal questão da censura do cinema educativo ser realizada por educadores, seus limites e poderes de deliberações. Algo que antes era realizado como exclusivamente policial e torna-se cultural. É importante perceber igualmente a alusão ao empenho do Governo em centralizar e nacionalizar as políticas públicas e um reconhecimento da contribuição do cinema à educação.

Uma das primeiras propostas colocadas dizia respeito à confusão no trabalho da polícia de censurar, realizado antes do Decreto 21.240 e após o Decreto. Sylvio Julio, o representante do chefe da polícia, defendeu que a situação precisava ser resolvida, já que para ele a formulação do Decreto estava errada: "a lei que antigamente regia a censura policial ainda não está em harmonia com a que dispõe sobre a censura cinematográfica." 
Grande parte das propostas dizia respeito à produção técnica dos filmes

educativos, seus valores e incentivos. A seguir, está a transcrição da proposta n. 5 feita por Carlos Magalhães Lebeis, representante do Juiz de Menores na Comissão, em relação à proibição de alguns filmes para crianças mesmo que estas estivessem acompanhadas de seus pais para assistir as películas:

O $1^{\text {a }}$ Convênio Cinematográfico Educativo estima que: - I - A censura cinematográfica é uma necessidade social e deve orientar-se num sentido educativo e protetor dos menores; II- As crianças de menos de seis anos não poderão em caso algum ser levadas as exibições cinematográficas; III- Os menores de doze anos, embora acompanhados de seus pais ou representantes legais, só poderão frequentar sessões cinematográficas quando os filmes não forem considerados impróprios pela comissão nacional de censura; Em qualquer caso, porém, não poderão esses menores frequentar as sessões que terminem depois de vinte horas; IV-É vedada aos menores de dezesseis anos, acompanhados ou não de seus pais ou responsáveis legais, a entrada em cinemas onde se exibem filmes julgados impróprios pela comissão nacional de censura; V- Será afixado claramente na entrada dos cinemas, bem como transcrito nos anúncios e programas, em que limites de idade o espetáculo é acessível, sendo proibida a venda de entradas aos menores impedidos por lei. (LEBEIS, 1933)

A proposta de Carlos Magalhães Lebeis foi criticada por Armanda Álvaro Alberto, que divergia sobre a quem cabia o papel de cuidar da censura realizada aos filhos. Armanda possuía uma experiência na Escola Regional de Meriti, especialmente no que diz respeito ao seu relacionamento com os pais dos alunos. Ela fundara o Círculo de Mães na Escola, em Meriti. Armanda acreditava e praticava o diálogo com os pais e responsáveis dos alunos, para a consolidação da aprendizagem e educação dos alunos. A educadora questionou se a censura moral que realizavam realmente lhes cabia como educadores. Como avaliar se um filme seria proibido para uma senhorita, por exemplo. A menção de palmas, na ata da reunião, na sequência da ponderação da educadora sugestiona a pertinência de sua argumentação diante dos demais participantes do Convênio:

Sr. Presidente, na qualidade de membro da Comissão de Censura solicito da Mesa que faça votar desde logo o pedido do sr. Magalhaes Lebeis.

A Comissão de Censura nada adianta dizer que um filme é impróprio para menores, quando são os pais ou responsáveis os primeiros a levar seus filhos as sessões impróprias. 
É de estranhar que nos venham em rosto que a culpa é nossa, porque, se deixamos certos filmes, fazemo-lo para os adultos e estes é que devem ter critério suficiente para distinguir o que lhes convém, permitindo, ou não, que seus filhos o assistam. Essas críticas, essas insinuações, ou censura obrigam-nos a declarar, como o faço neste instante, que seremos muito mais rigorosos daqui por diante, para que se não diga que no Rio, por culpa da Comissão de Censura, os menores assistem a filmes como "Monstros", e tantos outros. (palmas). (ALBERTO, 1933)

Nessa fala de Armanda há um enfrentamento das críticas ao trabalho da Comissão de Censura Cinematográfica, da qual fazia parte. Em outro momento, através das atas das sessões do Convênio, foi possível perceber novamente essa postura. A seguir, está a transcrição de um trecho do debate ocorrido entre alguns dos ali presentes, do qual Armanda participou:

O sr. Nobre de Almeida: -Desejo fazer uma ressalva nas minhas declarações: nelas não há nenhuma crítica a Comissão de Censura. Apenas, no Rio de Janeiro, a Polícia não cumpre as determinações dessa Comissão no tocante aos filmes considerados impróprios. A censura não tem função policial.

O sr. Sylvio Julio: - Não apoiado. Tem uma função policial, e esta é representada por mim.

A sra. Armanda Álvaro Alberto: - Sr. Presidente, fazendo parte da Comissão de Censura, desejava saber se o critério com que essa Comissão vem agindo está ou não dentro da lei e se este assunto está também em votação.

O sr. Presidente: - O Convênio nada tem a ver com a proposta do sr. Nobre de Almeida.

A sra. Armanda Álvaro Alberto: - Isto para nós é assunto importantíssimo. A proposta do sr. Nobre de Almeida envolve, indubitavelmente, uma censura.

O sr. Presidente: - O sr. Nobre de Almeida acaba de declarar que não teve a intenção de criticar a Comissão de Censura.

A sra. Armanda Álvaro Alberto: - S. Ex., alegou que, diariamente, assiste a cenas ofensivas a moral da família. Desejava saber se o critério da censura não está agradando. (ALMEIDA; JULIO; ALBERTO; ROQUETTEPINTO, 1933)

Em decorrência do posicionamento de Armanda em pedir explicações sobre os critérios do trabalho de censura realizado pela Comissão, no resumo sobre a sessão constava: "conclui deixando formulado seu protesto contra as referências a dita Comissão". O representante da polícia, Sylvio Julio argumentou igualmente contra a 
posição do Sr. Nobre de Almeida, dando até explicações mais longas, entretanto, aparece nos resumos como realizando ponderações. Armanda, sendo das poucas mulheres no Convênio, parece não ter tido suas posições validadas da mesma maneira de outros que partilhavam de opiniões semelhantes sobre o trabalho da Comissão.

Outra observação a partir do trecho acima diz respeito a uma possível divergência entre os membros da Comissão. O presidente do Convênio era Roquette Pinto e ele também presidia a Comissão e o Museu Nacional naqueles anos. As respostas do presidente do evento intervinham para que um diálogo sobre uma questão importante a outros membros da Comissão não tivesse prosseguimento. Contudo, mesmo Armanda e Sylvio Julio tendo opiniões similares no debate, a que foi supostamente compreendida como confrontante foi somente a de Armanda.

Uma das propostas foi feita por Armanda Álvaro Alberto, na categoria "diversas" do Convênio e por não suscitar divergência foi dispensada de discussão. Armanda postulou sobre a necessidade de uma diferenciação conceitual entre o cinema educativo e o cinema cultural. A ideia de cinema educativo vinha sendo utilizada em sentido amplo, entretanto, para Armanda o cinema educativo atendia a demandas diferentes do cinema cultural, em relação à população. Jonathas Serrano e Venâncio Filho (1930) concordavam sobre a necessidade da distinção entre as finalidades do cinema cultural e do cinema educativo. Segundo os autores, o cinema educativo deveria ter uma organização para alcançar seus objetivos e para isso deveria, primeiramente, estar sujeito aos preceitos gerais da pedagogia.

Em seguida, alguns dos participantes comentaram a respeito da importância de se compreender o cinema educativo como um dos meios de aprendizagem. E propuseram uma orientação sobre como deveria ser utilizado este tipo de cinema na escola: a exibição do filme deveria vir acompanhada de explicação, que poderia ser antes ou depois da película, fomentando o diálogo entre professor e alunos. 
Neste artigo buscou-se apresentar a censura vinculada à educação e trabalho de Armanda Álvaro Alberto como membro da Comissão de Censura Cinematográfica. O papel dos intelectuais nas sociedades é complexo e precisa ser observado pelas muitas redes que por este, podem ser estabelecidas. Pensar a relação do intelectual com os governos instituídos é sempre delicado, especialmente em um período de governo extenso e que passou por tantas transições, como o de Getúlio Vargas.

O Governo Provisório compreendeu um período de afirmação e consolidação, quando foi possível perceber um movimento de nacionalizar trabalhos e intelectuais que já vinham sendo realizado nas décadas anteriores, como sendo do Estado e passaram a ganhar um caráter centralizador e nacional. É interessante perceber também a tentativa de tornar a censura reflexiva ou teórica intelectualizada, como aponta Beatriz Kushnir (2004), ao conceberem intelectuais como censores.

A presença de Armanda Álvaro Alberto é paradigmática na referida Comissão. Ainda que fosse um momento anterior à ditadura varguista, quando ela foi entendida algumas vezes como oposta aos pressupostos do governo vigente, pela documentação da Comissão em que foi possível perceber alguns diálogos entre os membros desta, já havia demonstração de uma não aceitação de suas opiniões. As curtas falas de Armanda no Convênio Cinematográfico vinham seguidas de outras que as explicavam, como as de Carlos Magalhães Lebeis, Sylvio Julio ou Süssekind de Mendonça, seu marido.

Armanda, uma das poucas mulheres presentes no Convênio, foi a única da Comissão de Censura Cinematográfica, e ocupou lugares e debates em que as mulheres tinham pouca participação no período. Nas redes de sociabilidades das quais fazia parte, era uma das poucas mulheres. Sua prática na Comissão de Censura Cinematográfica parecia ser realizada de maneira diferenciada. Armanda entendia que o trabalho da Comissão era o de censurar os filmes, mas se os pais permitissem que seus filhos fossem acompanhados por maiores para assistir às películas impróprias para menores, isso competia à educação doméstica e não mais ao trabalho da Comissão. Ou seja, o trabalho de julgar moralmente as películas era possível respeitando certos limites, de não invadir esferas dos cuidados familiares sobre os seus filhos. 
A trajetória de Armanda, sua circularidade nas redes intelectuais de sua época e sua participação na Comissão de Censura Cinematográfica fazem perceber seu fundamental papel enquanto intelectual da educação, que refletia a partir das suas práticas. Mas há que se perceber o quanto muitas das sociabilidades exercidas por Armanda eram majoritariamente masculinas e como o lugar social da mulher não era fácil ou simples. Suas posições, como explicitado nas transcrições dos documentos, eram tidas como críticas.

O lugar de intelectual da educação engajada nas questões do seu tempo, em defesa de uma educação que enfrentava as desigualdades, com pertinência e arcabouço teórico ainda inspira e ensina a muitos. A participação de Armanda na Comissão de Censura Cinematográfica foi interessante e necessária. Em toda a documentação pesquisada, suas ponderações e posicionamentos foram elementares para fazer o contraponto reflexivo e / ou divergente. As vivências escolares da educadora fluíam e permeavam na sua vida e ofício. Na trajetória de Armanda Álvaro Alberto, a Escola Regional de Meriti foi o ponto de convergência dos seus aprendizados e ensinamentos. E, ainda que não tenha deixado escritos teóricos, como apontou Ana Chrystina Mignot (2010), o legado das suas experiências escolares está evidente nos documentos históricos e permanecem até hoje. 


\section{Referências}

ALBERTO, Armanda Álvaro. Atas taquigrafadas das sessões do Convênio Cinematográfico Educativo, 3-5 de janeiro de 1933. Notação: BR MN CCC. O. CC. 10, p. [158?]. Rio de Janeiro, 1933.

ALMEIDA, Nobre de; JULIO, Sylvio; ALBERTO, Armanda Álvaro; ROQUETTE-PINTO, Edgard. Atas taquigrafadas das sessões do Convênio Cinematográfico Educativo, 3-5 de janeiro de 1933. Notação: BR MN CCC. O. CC. 10, p. 123. Rio de Janeiro, 1933.

BENDA, Julien. A traição dos intelectuais. Trad. Paulo Neves. São Paulo: Peixoto Neto, 2007. $288 \mathrm{p}$.

BRASIL. Decreto 21.240, 4 de abril de 1932. Nacionalizar o serviço de censura dos filmes cinematográficos, cria a "Taxa Cinematográfica para a educação popular e dá outras providências”. Diário Oficial da União, Rio de Janeiro, Seção 1, p. 7146, abr. 1932.

BRASIL. Decreto 14.529, 9 de dezembro de 1920. Dá novo regulamento ás casas de diversões e espectaculos públicos. Diário Oficial da União, Rio de Janeiro, Seção 1, p. 21569, dez. 1920.

BURKE, Peter. História social do conhecimento: de Gutenberg a Diderot. Tradução de Plínio Dentzien. Rio de Janeiro: Jorge Zahar Editor, 2003.

BURKE, Peter; PALLARES-BURKE, Maria Lúcia G. Repensando os trópicos: um retrato intelectual de Gilberto Freyre. São Paulo: Editora UNESP, 2009.

GASPARELLO, Arlette Medeiros; VILLELA, Heloísa de Oliveira Santos. Intelectuais e Professores: identidades sociais em formação no século XIX brasileiro. Revista Brasileira de História da Educação (RBHE), Maringá, n. 21, p. 39-60, set./dez. 2009.

GOMES, Ângela de Castro. A invenção do trabalhismo. 3. ed. Rio de Janeiro: Editora FGV, 2005.

GOMES, Ângela de Castro. História e historiadores: a política cultural do Estado Novo. 2. ed. Rio de Janeiro: Editora FGV, 1999.

GOMES, Ângela de Castro; OLIVEIRA, Lúcia Lippi; VELLOSO, Mônica Pimenta. Estado Novo: ideologia e poder. Rio de Janeiro: Zahar Editores, 1982.

GOMES, Ângela de Castro; ABREU, Martha. A nova "Velha" República: um pouco de história e historiografia. Tempo, Rio de Janeiro, v. 13, n. 26, p. 1-14, 2009. Disponível em: http://www.scielo.br/pdf/tem/v13n26/a01v1326.pdf. Acesso em: 29 jan. 2013.

GOULART, Silvana. Sob a verdade oficial: ideologia, propaganda e censura no Estado Novo. São Paulo: Editora Marco Zero, 1990. 
KUSHNIR, Beatriz. Cães de Guarda: jornalistas e censores, do Al5 à Constituição de 1988. São Paulo: Boitempo Editorial, 2004.

LEBEIS, Carlos Magalhães. Proposta 5 do Convênio Cinematográfico Educativo, em 3 de janeiro de 1933. Notação: BR MN CCC. O. CC. 9, p. 17. Rio de Janeiro, 1933.

MIGNOT, Ana Chrystina Venâncio. Armanda Álvaro Alberto. Recife: Fundação Joaquim Nabuco: Editora Massangana, 2010. 164 p. (Coleção Educadores).

MORAES, José Damiro. Armanda Álvaro Alberto: Escola Nova e a repressão política nos anos 1930. Revista HISTEDBR On-line, Campinas, n. 53, p. 183-195, out. 2013.

PÉCAUT, Daniel. Os intelectuais e a política no Brasil: entre o povo e a nação. Trad. Maria Júlia Goldwasser. São Paulo: Ed. Ática, 1990.

PEREZ, Carmen Lúcia Vidal (org.) Experiências e narrativas em educação. Niterói: Eduff, 2017.

RANGEL, Jorge Antonio. Edgard Roquette-Pinto. Recife: Fundação Joaquim Nabuco: Editora Massangana, 2010.

RANGEL, Jorge Antonio (Fidel). Humberto Mauro. Recife: Fundação Joaquim Nabuco: Editora Massangana, 2010.

RIBEIRO, Mário Adalberto. O Instituto Nacional de Cinema Educativo. Revista do Serviço Público. Rio de Janeiro, ano 7, v. 1, n. 3, p. 4, mar. 1944.

RIBETTO, Anelice; FILÉ Valter. Da experiência à narrativa. In: PEREZ, Carmen Lúcia Vidal (org.) Experiências e narrativas em educação. Niterói: Eduff, 2017. p. 77-96.

ROQUETTE-PINTO, Edgard. Atas taquigrafadas das sessões do Convênio Cinematográfico Educativo, 3 de janeiro de 1933. Notação: BR MN CCC. O. CC. 10, p. 4. Rio de Janeiro, 1933.

SABA, Ana Gabriela. Intelectuais da educação na Comissão de Censura Cinematográfica (1932-1935). 2013. Dissertação (Mestrado em Educação) - Faculdade de Educação, Programa de Pós-graduação em Educação, Universidade Federal Fluminense, Niterói, 2013.

SERRANO, Jonathas; VENÂNCIO FILHO, Francisco. Cinema e educação. São Paulo: Editora Proprietária: Companhia Melhoramentos de São Paulo, 1930 (Biblioteca de Educação organizada por Lourenço Filho).

SIRINELLI, Jean-François. Os Intelectuais. In: RÉMOND, René. Por uma história política. Trad. Dora Rocha. 2. ed. Rio de Janeiro: Editora FGV, 2003. p. 231-269.

SODRÉ, Nelson Werneck. História da imprensa no Brasil. 4. ed. Rio de Janeiro: Mauad, 1999. 
SOUZA, José Inácio de Melo. O Estado contra os meios de comunicação (1889-1945). São Paulo: Annablume: Fapesp, 2003.

VIDAL, Diana Gonçalves. Escola Nova e processo educativo. In: LOPES, Eliane Marta, FARIA FILHO, Luciano Mendes e GREIVAS, Cynthia (orgs.). 500 anos de educação no Brasil. 3. ed. Belo Horizonte: Autêntica, 2010. p. 497-517.

VIEIRA, Carlos Eduardo. Intelligentsia e intelectuais: sentidos, conceitos e possibilidades para a história intelectual. Revista Brasileira de História da Educação, Campinas: Autores Associados, n. 16, p. 63-85, jan./abr. 2008.

Recebido em: 14/03/2021 Aprovado em: 29/05/2021

Universidade do Estado de Santa Catarina - UDESC Programa de Pós-Graduação em Educação - PPGE Revista Linhas Volume 22 - Número 50 - Ano 2021 revistalinhas@gmail.com 